\title{
ESTABLISHMENT AND CRYOPRESERVATION OF FIBROBLAST CELL LINE FROM A SUMATRAN RHINOCEROS (Dicerorhinus sumatrensis)
}

\author{
MELLINDA JENUIT ${ }^{1}$, ZAINAL ZAHARI ZAINUDDIN ${ }^{2}$, JUNAIDI PAYNE ${ }^{2}$, ABDUL HAMID \\ AHMAD $^{2,3}$, AFZAN MAT YUSOF ${ }^{4,5}$, MUHAMMAD LOKMAN MD ISA $^{4,5 *}$ AND MOUSTAFA \\ IBRAHIM $^{6}$
}

\begin{abstract}
${ }^{1}$ Department of Biotechnology, Kulliyyah of Science, International Islamic University Malaysia, Jalan Sultan Ahmad Shah, Bandar Indera Mahkota, 25200 Kuantan, Pahang, Malaysia. ${ }^{2}$ Borneo Rhino Alliance Berhad, Faculty of Science and Natural Resources, Universiti Malaysia Sabah, Jalan UMS, 88400 Kota Kinabalu, Sabah, Malaysia. ${ }^{3}$ Faculty of Sustainable Agriculture, Universiti Malaysia Sabah, Locked Bag No 3, 90509 Sandakan, Sabah, Malaysia. ${ }^{4}$ Department Basic Medical Sciences, Kulliyyah of Nursing, International Islamic University Malaysia, Jalan Sultan Ahmad Shah, Bandar Indera Mahkota, 25200 Kuantan, Pahang, Malaysia. ${ }^{5} I I U M$ Molecular and Cellular Biology Research Cluster (iMoleC), International Islamic University Malaysia, Jalan Sultan Ahmad Shah, Bandar Indera Mahkota, 25200 Kuantan, Pahang, Malaysia. ${ }^{6}$ Department of Physics, Faculty of Science, Benha University, Egypt 13518 Benha, Egypt.
\end{abstract}

*Corresponding author: lokman@iium.edu.my

Submitted final draft: 27 July $2020 \quad$ Accepted: 1 August 2020

http://doi.org/10.46754/jssm.2021.06.008

\begin{abstract}
Cell lines have been established to preserve the genetic material of endangered animals. This study aims to establish, characterize and authenticate fibroblast cells derived from the kidney tissue of a Sumatran rhinoceros' carcass. The primary cultures were obtained using the mixed enzymatic-explant method, supplemented with complete media and maintained at $37^{\circ} \mathrm{C}$ with $5 \% \mathrm{CO}_{2}$ in an incubator. Following routine trypsinization, viability and growth curves were generated through the Trypan Blue counting method. Cellular senescence was quantified by Sa- $\beta$-gal staining assay and G-banding for karyotyping. As a result, the cell derivation had generated 81 frozen stocks. The viability of cells at P5 and P10 showed reasonable recovery after six months. Cell population doubling time at P5 was 20.45 hours, while it was 22.35 hours at P10 and P15. The senescence level significantly increased from P5 to P10, and was especially significant at P15. Genetic stabilities were considered stable at P5 and P10, with frequency of over $70 \%$. In conclusion, this study was able to derive a primary fibroblast culture from the preserved tissue of a Sumatran rhinoceros, with certain changes in morphology, senescence level, growth curves and cell viability as the number of passages increased.
\end{abstract}

Keywords: Sustainability, Sumatran rhinoceros, fibroblast cells establishment, cryopreservation, characterization.

Abbreviations: DMEM, Dulbecco's modified Eagle's medium; FBS, Fetal bovine serum; Sa- $\beta$-gal, Senescence-associated beta-galactosidase; P5, Passage 5; P10, Passage 10; P15, Passage 15.

\section{Introduction}

Sumatran rhinoceros (Dicerorhinus sumatrensis) has been categorised a criticallyendangered wildlife by the International Union for Conservation of Nature (IUCN). As of 2015, the species has been assumed to be extinct in the wild in Malaysia (Havmoller et al., 2016). The country's last rhino in captivity, named Iman by its caretakers, has died on November 2019 at the Tabin Wildlife Reserve in Sabah. Despite its historical distribution in several Asian countries, presently, it is estimated that fewer than 80 individuals are still alive in Indonesia. Apart from conventional conservation efforts, the application of cell culture technology has emerged as a new tool for ex-situ conservation of this species (Ryder \& Onuma, 2018).

Establishment of cell lines have been widely used to preserve the genetic material of many rare and endangered animals, such as the Bengal tiger and jaguar (Guan et al., 2010; Mestre-Citrinovitz et al., 2016). This is further enhanced by cryopreservation techniques, which makes it possible to extend the storage 
of the established cell line. Advancements in cryopreservation will ensure the cell line's indefinite supply and distribution, preventing genetic and phenotypic instability, delay cell senescence and transformation, reduce the risk of contamination as well as for economic purposes. Several considerations must be taken into account before the development of a cell bank; provenance of the primary culture, quality, characterization and authentication of the cell line (Freshney, 2015).

Obtaining tissue sources for primary cell culture from living wildlife raises the concern of possible injury and even death to the animal. Therefore, tissue harvesting and preservation is usually done on deceased animals. On June $4^{\text {th }}$, 2017, a female Sumatran rhino named Puntung - the second last to survive in captivity in Malaysia - was euthanized due to terminal cancer. Tissue samples of the animal have been collected and distributed to several research institutions in Malaysia to be preserved and provide a source or generating primary cell cultures of the species. In the establishment of cell lines, characterization and authentication analyses are conducted to prevent misidentification and contamination of various cells. Herein, this study aims to establish, characterize and authenticate fibroblast cells derived from the kidney of a Sumatran rhinoceros' carcass.

\section{Materials and Methods}

\section{Tissue Sample Collection}

Tissue samples were obtained from the carcass of the female Sumatran rhino Puntung, which was euthanized at Tabin Wildlife Reserve Sabah due to terminal squamous cell cancer. The preserved tissues included the kidney, skin, gingiva, lung, heart, liver and ovaries. The tissues were transported to the International Islamic University Malaysia Kuantan campus to be processed for cell culture. Transportation from Sabah in Borneo to Kuantan, the capital of Pahang state in Peninsular Malaysia, took about nine hours. The tissues were transported in liquid media comprising DMEM (Nacalai
Tesque, Kyoto, Japan), 10\% of fetal bovine serum (Himedia Laboratories Pte Ltd, Mumbai, India) and $1 \%$ of antibiotic-antimycotic (Nacalai Tesque, Kyoto, Japan).

\section{Primary Culture of Kidney Tissues}

Small fragments of the rhino kidney tissues were transferred into one side of a petri dish and washed with complete DMEM. The tissues were then transferred into the other side of the dish filled with trypsin (Nacalai Tesque, Kyoto, Japan) and minced. Complete DMEM was added into the petri dish and the suspension was transferred into $15 \mathrm{ml}$ tubes and centrifuged for five minutes at 1,000 rpm. The supernatant was discarded and the pellet was re-suspended with fresh complete DMEM. The suspension was then seeded into a 12-well plate and incubated at $37^{\circ} \mathrm{C}$ with $5 \% \mathrm{CO}_{2}$.

\section{Routine Subculture}

When cells reached 80-90\% confluency, the used media was discarded and the cells in the culture flasks were washed with PBS. Trypsin/ EDTA was pipetted into the flasks and incubated for three minutes at $37^{\circ} \mathrm{C}$ with $5 \% \quad \mathrm{CO}_{2}$ to release the monolayer cells adhered to the flask surface. The culture flask was also gently shaken to further detach and disassociate the cells. Complete DMEM was added into the flask and transferred into $15 \mathrm{ml}$ tubes to be centrifuged at $1,000 \mathrm{rpm}$ for three minutes. The supernatant was discarded and fresh complete DMEM was used to re-suspend the cell pellet. The resuspended cells were split at the ratio of 1:2 and seeded into new culture flasks, before being incubated at $37^{\circ} \mathrm{C}$ with $5 \% \mathrm{CO}_{2}$. Culture media refreshments were done every two to three days after seeding. The cell line code name, passage number, date and initials were labelled at the side of the culture flasks.

\section{Cryopreservation and Recovery}

After the addition of complete DMEM to cells detached by Trypsin/EDTA, the cell suspensions were transferred into $15 \mathrm{ml}$ tubes and centrifuged at $1,000 \mathrm{rpm}$ for three minutes. The supernatant 
was discarded and the pellet was resuspended with freezing medium $(90 \%$ fetal bovine serum $+10 \%$ DMSO). Approximately $1 \mathrm{ml}$ of cell suspension was dispensed into $1.8 \mathrm{ml}$ cryogenic vials; labelled with the cell line code name, passage number, date and initials. The cryogenic vials were placed in a freezing container and immediately moved to a $-80^{\circ} \mathrm{C}$ freezer.

To recover the cells, frozen vials were taken out of the $-80^{\circ} \mathrm{C}$ freezer and immediately thawed in a water bath at $37{ }^{\circ} \mathrm{C}$ until the suspension had melted. The cells were transferred into 15 $\mathrm{ml}$ tubes and mixed with pre-warmed complete DMEM $\left(37^{\circ} \mathrm{C}\right)$ and centrifuged at $1,000 \mathrm{rpm}$ for two minutes. The supernatant was discarded, followed by re-suspension of cell pellets with complete DMEM. Cells from each revived cryovial were seeded into 12 wells of a 24 -well plate.

\section{Cell Viability}

Cell viability assay was carried out before cryopreservation and after thawing the cells using the Trypan Blue staining method. A total of $10 \mu \mathrm{l}$ was taken from a freshly re-suspended cell culture and mixed with $10 \mu$ l of Trypan Blue dye. Half of the mixture was then loaded onto a chamber of a haemocytometer. When viewed under the microscope, viable cells would appear clear, whereas non-viable ones were blue. All cells (blue and clear) were counted to determine the total number of cells per ml, while clear ones were counted only for total viable cells. The percentage of viable cells was then calculated using Equation 1:

$\%$ of viable cells $=\frac{\text { no. of viable cells } \mathrm{x} 100}{\text { total no. of cell }}$

(Equation 1)

\section{Growth Curve Analysis}

Cells were seeded in 24-well plates with a density of $2 \times 10^{4}$ cells $/ \mathrm{ml}$ per well. Cells in three wells were detached, re-suspended and counted every day for eight days, and the mean number of cells were calculated and plotted in a graph to describe the growth curve. The population doubling time (PDT) was calculated based on the generated curves, using the formula in Equation 2.

$\mathrm{PDT}=\mathrm{T} \ln 2 / \ln (\mathrm{Xe} / \mathrm{Xb})$

(Equation 2)

where $\mathrm{T}$ is the incubation time; $\mathrm{Xe}$ is the cells number at the end of incubation; $\mathrm{Xb}$ is the cells number after seeding.

\section{Senescence Staining}

The Cellular Senescence Assay Kit (Cell Biolabs, San Diego, CA, USA) was used for senescence-associated- $\beta$-galactosidase (SA- $\beta$ gal) staining. At 80-90\% confluency, cells grown in $35 \mathrm{~mm}$ well plates were stained according to the manufacturer's protocol. Away from direct light, freshly prepared staining working solution was then added to the cells and incubated for 48 $\mathrm{h}$ at $37^{\circ} \mathrm{C}$ with $5 \% \mathrm{CO}_{2}$.

The staining solution was then discarded and the cells were washed with PBS twice. For each well plate, five images were captured at different areas. The levels of cells senescence were measured using the ImageJ software (https://imagej.nih.gov/ij/) by the United States National Institutes of Health. The software was used to produce 16-bit images of the cells in the wellplate by selecting "Image $>$ Type $>16$ bit". Then, the images were adjusted selecting "Image $>$ Adjust $>$ Threshold" to highlight the area of positively-stained cells. For analysis, functions "Analyze/Analyze Particles" were selected before checking "Summarize". The density of the positively-stained cells would be taken from the "\%Area" shown in the "Summary" window. The techniques were repeated, but highlighting all the cells from the same images. The percentages of senescent cells were calculated using the "\%Area" of stained cells over total cells.

\section{Detection of Mycoplasma Contamination}

Screening of mycoplasma contamination was performed at the Molecular Biology Institute of Universiti Kebangsaan Malaysia in Bangi, Selangor. The cells at passage (P) 5, P10 and P15 were prepared in IIUM. Used media was 
first discarded before the cells in the flasks were washed with PBS. Trypsinization was conducted for two to three minutes, followed by addition of complete media. The suspensions was transferred into $15 \mathrm{ml}$ tubes and centrifuged at $1,000 \mathrm{rpm}$ for three minutes. The supernatant was discarded, the pellets were re-suspended with $1 \mathrm{ml}$ PBS and transferred into $1.5 \mathrm{ml}$ tubes. The suspensions were centrifuged at $1,000 \mathrm{rpm}$ for three minutes. The supernatant was discarded and the pellets were re-suspended in $200 \mu \mathrm{l}$ PBS. The tubes were sealed with parafilm tape and labelled with their corresponding passage number. The P5, P10 and P15 tubes were then enclosed into a petri dish, sealed with parafilm and packed into a polystyrene box containing dry ice and ice packs for transport. Upon arrival at the UKM facility, the cells were stored in a $-20^{\circ} \mathrm{C}$ freezer for three days.

DNA extractions were carried out using DNeasy $^{\circledR}$ Blood \& Tissue kit (QIAGEN, Dusseldorf, Germany) according to the manufacturer's instructions. The e-Myco ${ }^{\mathrm{TM}}$ Mycoplasma PCR Detection Kit ver.2.0 (iNtRON Biotechnology, Seongnam-si, South Korea) was used to detect the presence of mycoplasma. Five tubes of PCR pre-mixture were prepared for the following samples positive control, negative control, P5, P10 and $\mathrm{P} 15$. Each cell sample tubes were added with 10 $\mu 1$ DNase-free water and $10 \mu \mathrm{l}$ of 100 ng DNA template. For positive control, $19 \mu \mathrm{l}$ of DNasefree water was added with $1 \mu \mathrm{l}$ of $M$. hyorhinis control sample provided in the kit. The negative control consisted of $20 \mu \mathrm{l}$ DNase-free water only. The tubes were vortexed before being subjected to PCR.A total of $5 \mu \mathrm{l}$ of the PCR products from each sample were subjected to electrophoresis in $1.5 \%$ agarose gel in TBE buffer ( $80 \mathrm{~V}, 60 \mathrm{~min})$. The gel was incubated in SYBR staining buffer for 30 minutes and visualized under a blue light transilluminator.

\section{Karyotyping}

Karyotype analysis was carried out according to chromosome preparation methods from adherent cultured cells (Menon et al., 2012). Cells were harvested when the confluency reached $80 \%$. Following incubation in hypotonic solution of $0.075 \mathrm{~mol} / \mathrm{L} \mathrm{KCl}$ for $20 \mathrm{~min}$, the chromosomes were fixed using Carnoy's fixative (1 glacial acetate: 3 methanol). Under light microscope at $100 \times$ magnification, chromosome numbers from 20 metaphase spreads were counted.

\section{Results and Discussion}

\section{Outgrowth of Primary Cells and Morphology}

Mixed enzymatic-explant method was successfully used to isolate the primary cultures from kidney tissue of a Sumatran rhinoceros carcass (Figure 1). No cell outgrowth was observed from other tissue samples. Under inverted microscope at $4 \times$ magnification, the kidney fibroblast cells displayed fibroblast-like spindles throughout P5, P10 and P15 as shown in Figure 2. At P5, the cells were mostly small in size. While the cells retained their previous spindle-shaped morphology and size, some became more elongated at P10. Finally, at P15, the cells appeared large with some showing flattened and irregular shapes.

Partial treatment of kidney tissues with trypsin had digested the extracellular matrix and cellular junctions at the exposed outer layer, leaving the tissue edges appearing loose or sticky-like. The outer layer was likely epidermis comprising mainly of keratinocytes, while fibroblast could be found within the inner layer or the dermis (Orazizadeh et al., 2015). As a result, the keratinocytes had migrated out from the tissue explant earlier, which was observed on Day 7. As keratinocytes had relatively low proliferation capacity (Siengdee et al., 2018), the primary cell population would consist of fibroblasts at Day 14. For the first few days, tissue explants were also sources for cell migration (Moore \& Maitland, 2013; Aoued $\&$ Singh, 2015). Outgrowth of cells from the explant source resulted in an area with high number of cells that gradually spread outward.

Immediate primary cultures were not able to be carried out in this study. Hence, the interval between tissue harvesting to preservation was 
critical in ensuring minimal loss of cell viability. With immediate preservation, several successful establishments of fibroblast cells had been reported at different storage temperatures in complete media. Viable cells from goat tissues were reported up to 160 days post-mortem when stored at at $4{ }^{\circ} \mathrm{C}$ (Moore \& Maitland, 2013). In Angus cattle tissues, viable cells could be observed after 49 days when stored at $4{ }^{\circ} \mathrm{C}$ and 15 days at $25^{\circ} \mathrm{C}$ (Walcott \& Singh, 2017). In mouse tissues, they could still be observed after 10 days at $25^{\circ} \mathrm{C}$ (Khan \& Gasser, 2016).
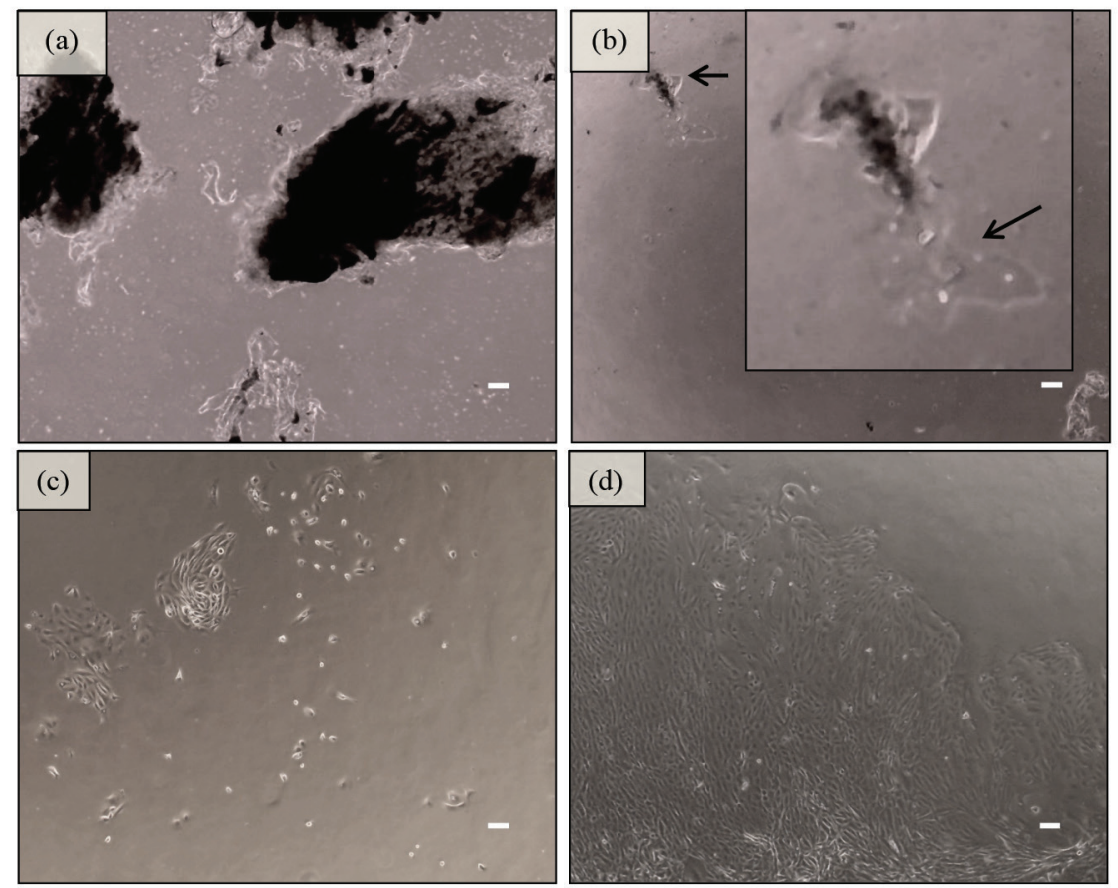

Figure 1: Outgrowth of primary cultures derived from kidney tissue of Sumatran rhinoceros, where the resulting fibroblast cells were designated as KDF (Kidney fibroblast) cells. Scale bar: $100 \mu \mathrm{m}$. At Day

0 , trypsin-treated tissues were seeded into the culture flask with no cell attachments (a). Arrow showing keratinocytes migrating out of attached tissues on Day 7 (b). Spindle-shaped cells predominate at Day 14 (c).

Primary fibroblast cells spread from the compact source area outward (d) 

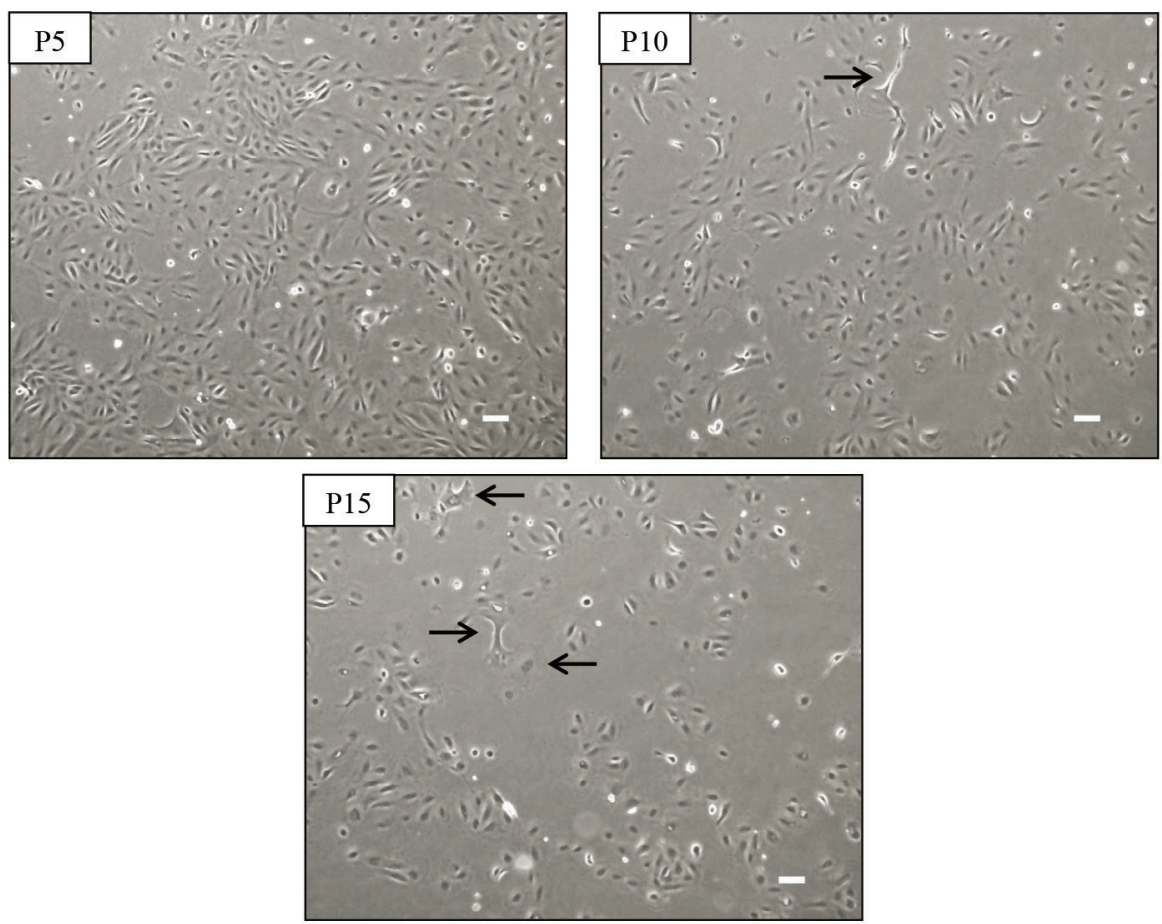

Figure 2: Morphology of kidney fibroblast cells during serial passages. Arrows show elongated, flattened and irregular cells as the passages increased. Scale bar: $100 \mu \mathrm{m}$

\section{Cellular Senescence}

Negatively-stained cells displayed normal pale-like colour, while positively-stained cells appeared blue-greenish (Figure 3). The number of positively stained cells increased from P5 to P10, and eventually to P15. The senescence level increased significantly from P5 to P10, and was especially significant in contrast to P15. From P10 to P15, the senescence level increased significantly (Figure 4). The progression of fibroblast morphology with increasing passage number was described as small spindle-shaped at early passages, which gradually increased in size and length at middle passages, before becoming flattened and irregular at late passages (Lian et al., 2016). As passage number increased, senescent morphologies also intensified, in which cells exhibited cytoplasmic enlargements and became flattened and irregular. These might be accompanied by numerous visible nuclei, vacuoles and lysosomal bodies. Actin, which is the cytoskeletal protein that provided mechanical support and shape to fibroblast cells, was down-regulated during senescence (Phipps et al., 2007; Chen et al., 2013). In addition, there was a reduction in saturation densities of cell monolayers, which referred to the number of cells per unit area. This was due to increased sensitivity of cell-cell contact inhibition as the cells aged (Schulz et al., 2006).

Blue-stained cells indicated the presence of cytoplasmic $\beta$-gal - a biomarker for cell senescence. The use of 5-bromo-4-chloro-3indoyl $\beta$-D-galactopyranoside or $\mathrm{X}$-gal as a substrate in Sa- $\beta$-gal assay would produce blue insoluble precipitates when it was hydrolyzed by $\beta$-gal. This correlated with the level of lysosomal $\beta$-gal expressed in the cells. The lysosomal bodies were prominent in the organs of aged animals, as well as in therapyinduced senescence in cancer cell lines (Lee et al., 2006; Wagner et al., 2015). For finite cell lines, cells within early passages expressed minimal level of $\beta$-gal, and would eventually cease to survive when senescent populations exceeded proliferating cells at later passages 
(Estrada et al., 2013). The mouse embryonic fibroblasts cell line (MEF) displayed the same trend, but some cells survived beyond the senescent phase, which resulted in significant drop in Sa- $\beta$-gal expression. This is known as

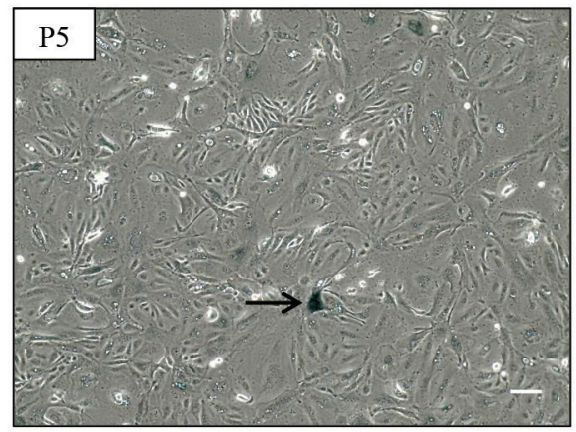

spontaneous immortalization of cells (Yang et al., 2017). The kidney fibroblast cells displayed similar increasing trend of Sa- $\beta$-gal expression level, with no indication of spontaneous immortalization.

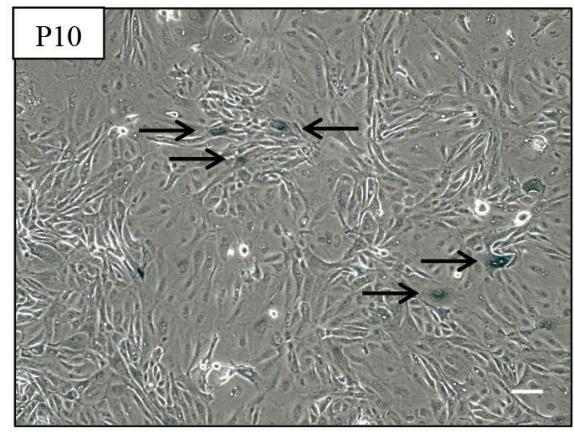

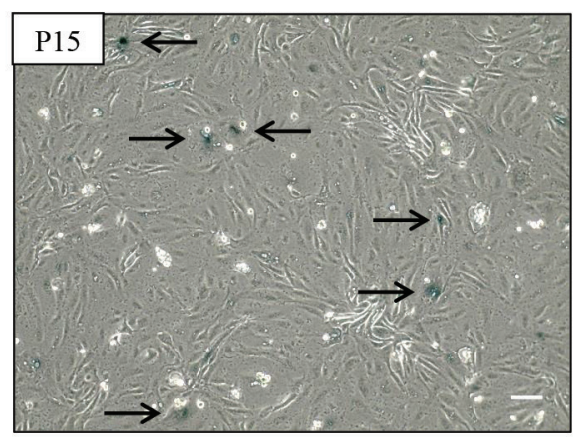

Figure 3: Senescence-associated- $\beta$-galactosidase (Sa- $\beta$-gal) staining of kidney fibroblast cells at P5, P10 and P15. Arrows indicate positively-stained cells. Scale bar: $100 \mu \mathrm{m}$

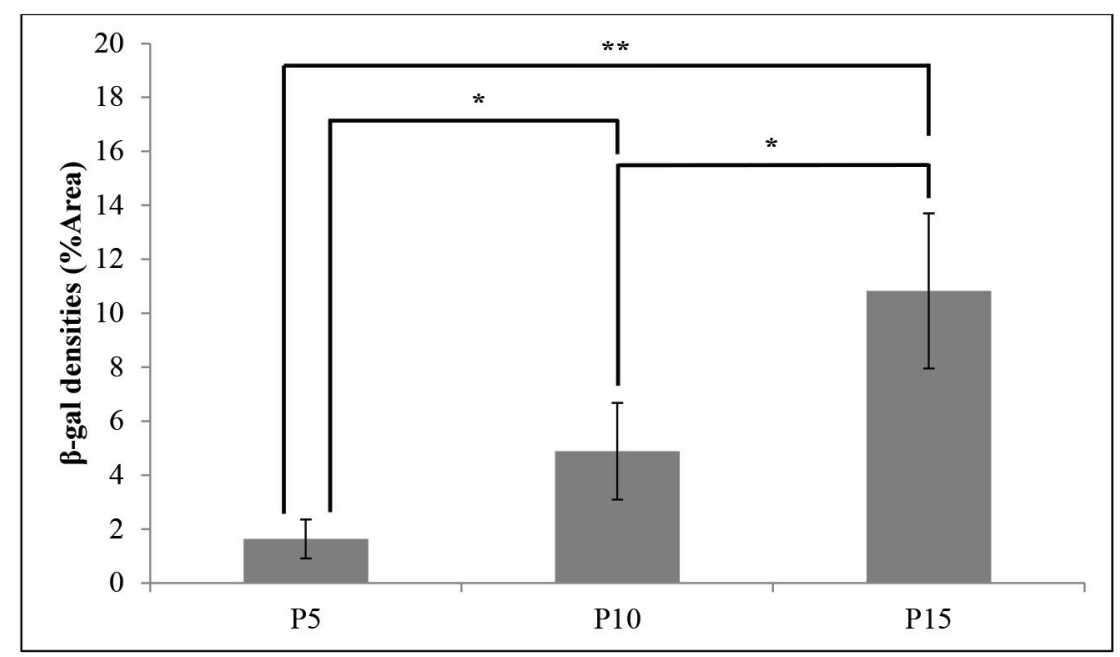

Figure 4: $\beta$-gal densities of positively stained kidney fibroblast cells. Using t test, differences were considered significant at $* \mathrm{P}<0.05$ and especially significant at $* * \mathrm{P}<0.01 \quad(\mathrm{n}=5)$ 


\section{Cell Viability}

This study could maintain the pre-thaw viability of kidney fibroblast cells at more than $80 \%$ up to P15. After 3 months of cryopreservation, there was no significant decrease in viability of all cells (Figure 5), which remained within the 80 $\%$ range. After six months of cryopreservation, the cells at P5 and P10 showed a significant drop in viability to $73.6 \pm 3.9 \%$ and $72.5 \pm 3.3 \%$, respectively. The cells at $\mathrm{P} 15$ showed significant drop in viability at $66.8 \pm 1.1 \%$.

According to World Health Organization, animal cell cultures should possess high viability level of more than $80 \%$. The use of the Trypan Blue exclusion method for viability assessment was prone to over-calculation due to the inability of early pre-apoptotic cells to absorb the dye, and might also underestimate the exposure duration of cells to the dye. Thus, cells with lower viability would be acceptable, but they should not be significantly lower than the standard baseline $(80 \%)$. Cells at different passages managed to maintain high viabilities within the $80 \%$ range during serial passaging and after three months of cryopreservation. After six months, the cells at P5 and P10 showed significant decreased in viabilities at the $70 \%$ range, while P15 was within the $60 \%$ range. Prolonged preservation of cells within $-80{ }^{\circ} \mathrm{C}$ had caused the accumulation of dead cells due to dehydration, since their metabolism had been relatively slowed down. Meanwhile, cells could be recovered from liquid nitrogen up to eight years as the cells' metabolism had became dormant or completely stopped (Mishra et al., 2010).

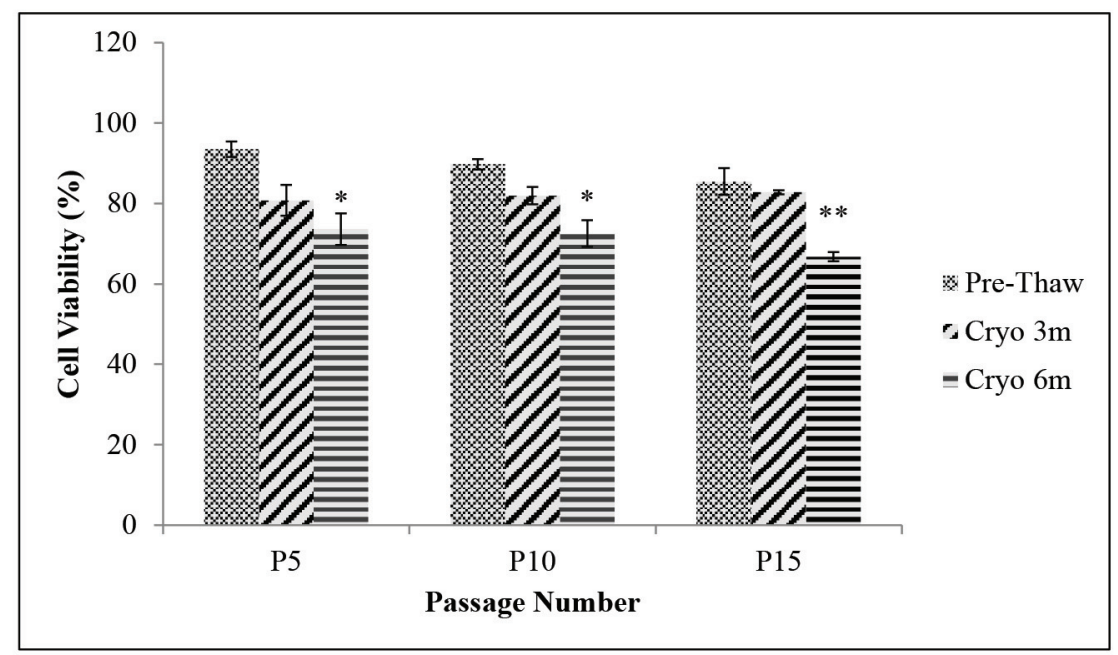

Figure 5: Kidney fibroblast cell viability pre-thaw and post-thaw in P5, P10 and P15 cryopreserved for three and six months. Using the $\mathrm{t}$ test, significant differences have been observed at $* \mathrm{P}<0.05$ and $* * \mathrm{P}<0.01(\mathrm{n}=3)$

\section{Cell Growth Curves}

The kidney fibroblast cells displayed a sigmoidal growth curve - lag, logarithmic and plateau phase (Figure 6). The peak cell numbers would decrease with the number of passages. The PDT was $20.45 \mathrm{~h}$ at P5, and 22.35 $\mathrm{h}$ at $\mathrm{P} 10$ and P15. As the cells aged, saturation density decreased, resulting in lower total cell number with increasing passage number. Besides, the gradual increase in cell size was further limited by the increasing sensitivity to cell-cell contact inhibition (Schulz et al., 2006; Neuhuber et al., 2008). During lag phase, cells adhesion and adaptation takes place, which resulted in relatively slow growth. After seeding, electrostatic interaction between cells and the surface of the culture flask would cause sedimentation followed by integrin bonding. This mediated the interaction between the cells' cytoskeleton to adhere to the embedded 
extracellular matrix (Khalili \& Ahmad, 2015). During logarithmic phase, the cells actively divided until the saturation density reached its highest. The population doubling time should be determined during this period (Davis, 2011). During plateau phase, further cell proliferation and growth were limited by their contact inhibition properties. Thus, the cell population had become stagnant. These cells could be in quiescence or senescence (Pavel et al., 2018). Although proliferation had ceased, cells at plateau phase still carried out their metabolic activities, thus using up nutrients in culture media much faster. In addition to a natural death cycle or programmed apoptosis, prolonged nutrient exhaustion would also induce apoptosis (Caro-Maldonado \& Muñoz-Pinedo, 2011).

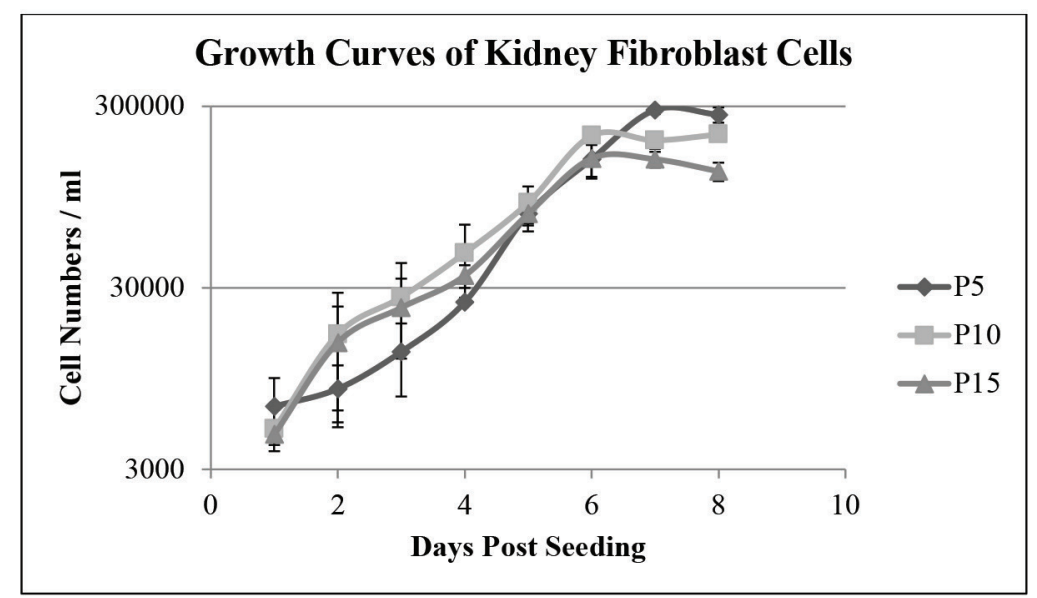

Figure 6: Logarithmic $\left(\log _{10}\right)$ growth curves of kidney fibroblast cultures at P5, P10 and P15. Bars indicate standard deviation $(\mathrm{n}=3)$

\section{Karyotyping}

Normal Sumatran rhinoceros cells contained 82 (2n) chromosomes, comprising 80 acrocentric autosomes and two large submetacentric $\mathrm{X}$-chromosomes (Figure 7). In the karyotype study, the autosomes were aligned in descending order according to size, and the X-chromosomes were placed at the lower right. The frequency of 20 metaphase spreads having the normal chromosome number would decrease with passage number: $85 \%$ at $\mathrm{P} 5,70 \%$ at $\mathrm{P} 10$ and 45 $\%$ at $\mathrm{P} 15$. Chromosomal instability, described as the increased rate of chromosome segregation error during cell division, was a major indication of genomic instability (Bolhaqueiro et al., 2019). Aneuploidy, frequently linked with chromosomal instability, was the random loss or gain of chromosomes to that of diploid cells (Gordon et al., 2012). It arose as a result of defects in kinetochore-microtubule attachments and dynamics, centrosome amplification, dysfunction of spindle assembly checkpoint and chromosome cohesion (Bakhoum et al., 2015). In addition, telomere attrition was also linked to chromosomal instability, which was caused by the sticky ends that likely resulted in end-toend fusion of chromosomes. Telomere attritions occurred as cells underwent division, thus, the rate of chromosomal instability increased with higher passage number. Frequency of cells cultures with normal diploid number of more than $70 \%$ were considered chromosomally stable (Mastromonaco et al., 2006). The chromosome analysis of kidney fibroblast cells showed that only cells up to P10 were stable in vitro. 


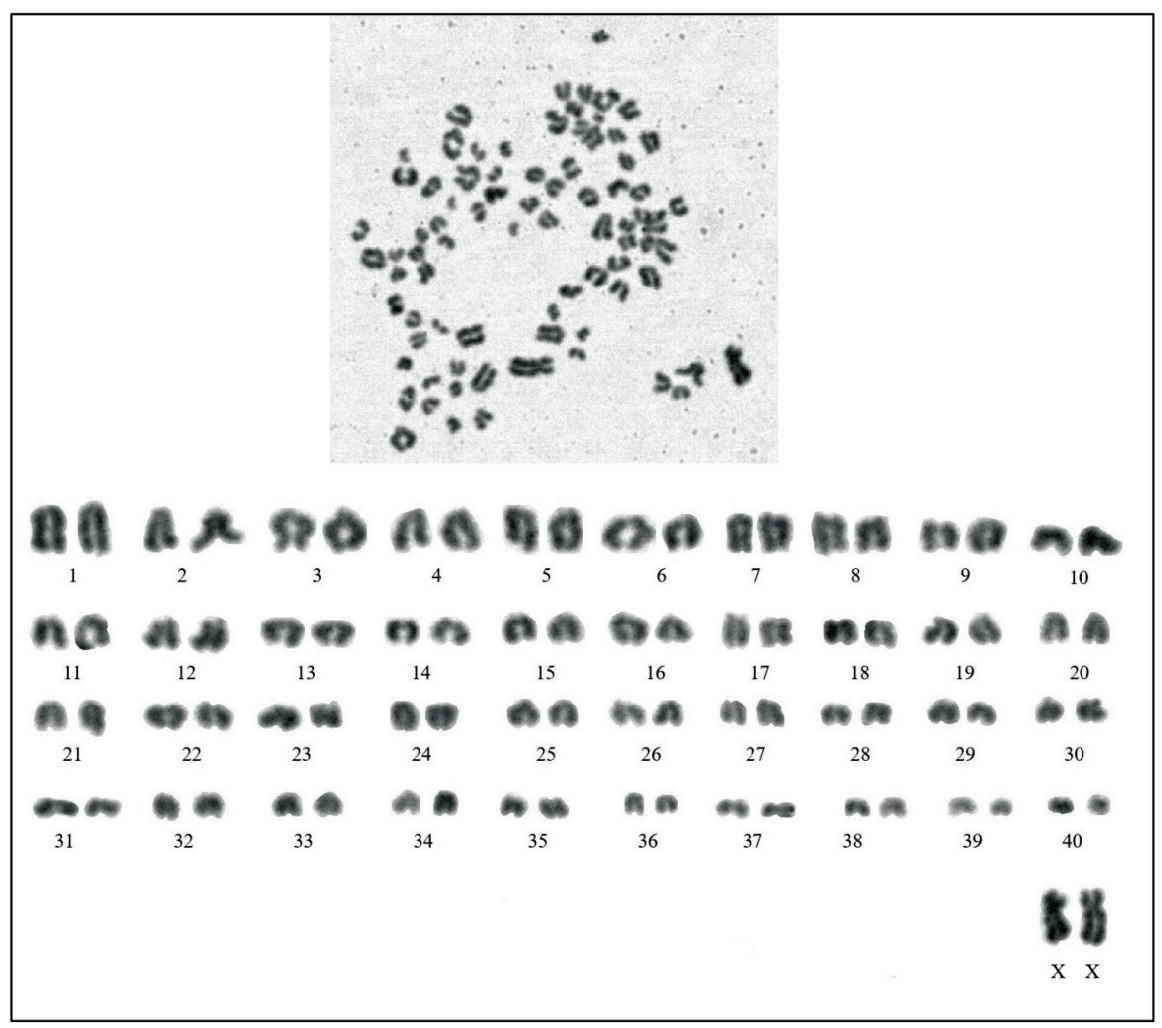

H1gure /: Karyotype of k1dney nbroblast cell

\section{Mycoplasma Detection}

The primer used in the PCR reaction was derived from the highly conserved region within the $16 \mathrm{~S}$ rRNA of the mycoplasma gene, which allowed the detection of $M$. arginini, $M$. fermentans, $M$. hyorhinis, M. orale and Acholeplasma laidlawii. No mycoplasma amplicons were produced within the sample lanes of cells at P5, P10 and $\mathrm{P} 15$, indicating the absence of mycoplasma contamination (Figure 8). Mycoplasma contamination was a major problem in cell culture, with the incidence ranging from 1-5\% in primary and finite cultures in contrast to 15-35 $\%$ in continuous cell lines worldwide. Being the smallest replicating bacteria lacking cell wall, visual detection and prevention by antibiotics were unreliable.

PCR method for mycoplasma detection offered clear and fast results in terms of sensitivity and specificity compared to conventional culture test and DNA staining (Rottem, 2012). Wide strains of mycoplasma could be detected with the use of specific primers that targeted their highlyconserved gene coding sequence for 16S rRNA (Hong et al., 2012). This PCR-based method required the use of appropriate controls which included internal controls in addition to the usual positive and negative ones. An internal control contained the same sequence as the primer, but was extended with interspersed DNA for size distinction. It was used in a limiting dilution high enough to detect the presence of inhibitory components, but low enough to compete with the primers. Positive control would show the expected results of a contamination while the negative control would show no amplicons if the PCR reaction was optimal (Uphoff \& Drexler, 2004; Ingebritson et al., 2014). 


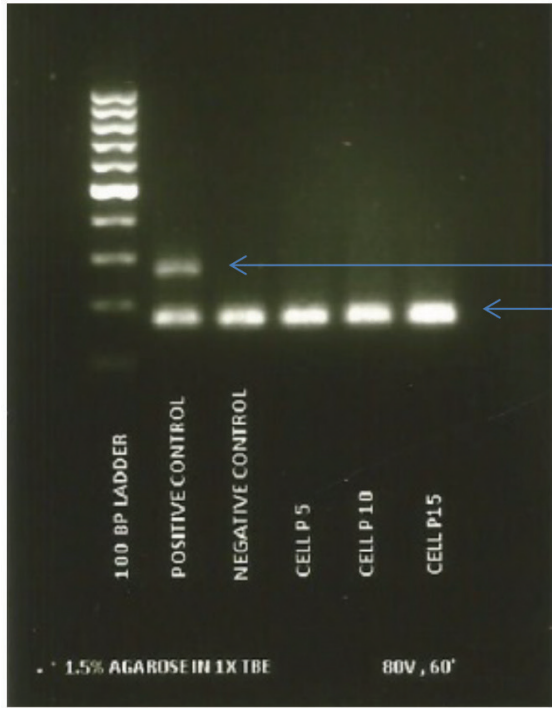

Mycoplasma, $\approx 270 \mathrm{bp}$

Internal Control, $\approx 160 \mathrm{bp}$

Figure 8: Electrophoresis bands of PCR products in the mycoplasma detection test of cell cultures in P5, P10 and $\mathrm{p} 15$

\section{Limitations of the Study}

This cell culture study was limited to one type of fibroblast cell only (kidney). Derivation of other tissues of the species would be useful to explore the various characteristics of the cells. It was also important to study the molecular characteristics of the cells. These findings might assist in identifying the function of cells for future applications in animal conservation.

\section{Conclusion}

A primary fibroblast culture was derived from kidney tissues collected from the carcass of an endangered Sumatran rhinoceros using mixed enzymatic-explant method, which exhibited certain changes in morphology, senescence level, growth and viability with increasing number of passages. The optimization of culture and freezing media, and assessment of contaminations were important for the cell banking system. There was one point where the properties of cells deviated from normal, which defeated its purpose; thus, passaging should be minimised unless for restocking and experimental purposes (Kwist et al., 2016). Therefore, the kidney fibroblast cells at P10 should be the cut-off point for banking of Sumatran rhino fibroblast cells for future applications, such as cloning and stem cell technology.

\section{Acknowledgements}

This study was supported by the Malaysian Water, Land and Natural Resources Ministry and the Sabah Wildlife Department, which funded the project entitled "Application of Advanced Reproductive Technology in Conservation of Endangered Species in Sabah" (Project ID: JHL/ $\mathrm{C} / 001 / 2016(\mathrm{~K}))$ together with other institutions like IIUM.

\section{References}

Aoued, H. S., \& Singh M. (2015). Recovery of fibroblast-like cells after 160 days of postmortem storage of goat skin tissues in refrigerated media. Journal of Veterinary Science \& Technology, 06(04), 2-5. https:// doi.org/10.4172/2157-7579.1000236

Bakhoum, S. F., Silkworth, W. T., Nardi, I. K., Nicholson, J. M., Compton, D. A., \& Cimini, D. (2014). The mitotic origin of chromosomal instability. Current 
Biology, 24(4), R148-R149. https://doi. org/10.1016/j.cub.2014.01.019

Bolhaqueiro, A. C. F., Ponsioen, B., Bakker, B., Klaasen, S. J., Kucukkose, E., van Jaarsveld, R. H., ... Kops, G. (2019). Ongoing chromosomal instability and karyotype evolution in human colorectal cancer organoids. Nature Genetics, 51(5), 824-834. https://doi.org/10.1038/s41588019-0399-6

Caro-Maldonado, A., \& Muoz-Pinedo, C. (2011). Dying for something to eat: How cells respond to starvation. The Open Cell Signaling Journal, 3, 42-51. https://doi. org/10.2174/1876390101103010042

Chen, H., Li, Y., \& Tollefsbol, T. O. (2013). Cell senescence culturing methods. Methods in Molecular Biology (Clifton, N.J.), 1048, 1-10. https://doi.org/10.1007/978-1-62703556-9_1

Davis, J. M. (2011). Animal cell culture / Elektronische Ressource. Chichester: Wiley-Blackwell.

Estrada, J. C., Torres, Y., Benguría, A., Dopazo, A., Roche, E., Carrera-Quintanar, L., Pérez, R. A., Enríquez, J. A., Torres, R., Ramírez, J. C., Samper, E., \& Bernad, A. (2013). Human mesenchymal stem cell-replicative senescence and oxidative stress are closely linked to aneuploidy. Cell Death \& Disease, 4(6), e691. https://doi.org/10.1038/ cddis. 2013.211

Freshney, R. I. (2015). Culture of animal cells: A manual of basic technique and specialized applications (7th ed., pp. 187-196). New York: John Wiley \& Sons.

Gordon, D. J., Resio, B., \& Pellman, D. (2012). Causes and consequences of aneuploidy in cancer. Nature Reviews Genetics, 13(3), 189-203. https://doi.org/10.1038/nrg3123

Guan, W. J., Liu, C. Q., Li, C. Y., Liu, D., Zhang, W. X., \& Ma, Y. H. (2010). Establishment and cryopreservation of a fibroblast cell line derived from Bengal tiger (Panthera tigris tigris). Cryo Letters, 31(2), 130-138.
Havmøller, R., Payne, J., Ramono, W., Ellis, S., Yoganand, K., Long, B., ... Burgess, N. (2016). Will current conservation responses save the critically endangered Sumatran rhinoceros Dicerorhinus sumatrensis? Oryx, 50(2), 355-359. https://doi.org/10.1017/ S0030605315000472

Hong S, Park S. H., Chung Y. H., \& Kim O. (2012). A newly developed consensus polymerase chain reaction to detect Mycoplasma species using 16S ribosomal RNA gene. Hanguk Kachuk Wisaeng Hakhoe Chi, 35(4), 289-294. https://doi. org/10.7853/KJVS.2012.35.4.289

Ingebritson, A. L., Gibbs, C. P., Tong, C., \& Srinivas, G. B. (2015). A PCR detection method for testing Mycoplasma contamination of veterinary vaccines and biological products. Letters in Applied Microbiology, 60(2), 174-180. https://doi. org/10.1111/lam.12355

Khalili, A. A., \& Ahmad, M. R. (2015). A review of cell adhesion studies for biomedical and biological applications. International Journal of Molecular Sciences, 16(8), 18149-18184. https://doi.org/10.3390/ ijms 160818149

Khan, M., \& Gasser, S. (2016). Generating primary fibroblast cultures from mouse ear and tail tissues. Journal of Visualized Experiments: JoVE, (107), 53565. https:// doi.org/10.3791/53565

Kwist, K., Bridges, W. C., \& Burg, K. J. (2016). The effect of cell passage number on osteogenic and adipogenic characteristics of D1 cells. Cytotechnology, 68(4), 16611667. https://doi.org/10.1007/s10616-0159883-8

Lee, B. Y., Han, J. A., Im, J. S., Morrone, A., Johung, K., Goodwin, E. C., Kleijer, W. J., DiMaio, D., \& Hwang, E. S. (2006). Senescence-associated beta-galactosidase is lysosomal beta-galactosidase. Aging Cell, 5(2), 187-195. https://doi.org/10.1111/ j.1474-9726.2006.00199.x 
Lian, J., Lv, S., Liu, C., Liu, Y., Wang, S., Guo, X., Nan, F., Yu, H., He, X., Sun, G., \& Ma, X. (2016). Effects of serial passage on the characteristics and cardiac and neural differentiation of human umbilical cord Wharton's Jelly-derived mesenchymal stem cells. Stem Cells International, 2016, 9291013. https://doi. org/10.1155/2016/9291013

Mastromonaco, G. F., Perrault, S. D., Betts, D. H., \& King, W. A. (2006). Role of chromosome stability and telomere length in the production of viable cell lines for somatic cell nuclear transfer. $B M C$ Developmental Biology, 6, 41. https://doi. org/10.1186/1471-213X-6-41

Menon, S. N., Flegg, J. A., McCue, S. W., Schugart, R. C., Dawson, R. A., \& McElwain, D. L. (2012). Modelling the interaction of keratinocytes and fibroblasts during normal and abnormal wound healing processes. Proceedings. Biological Sciences, 279(1741), 3329-3338. https:// doi.org/10.1098/rspb.2012.0319

Mestre-Citrinovitz, A. C., Sestelo, A. J., Ceballos, M. B., Barañao, J. L., \& Saragüeta, P. (2016). Isolation of primary fibroblast culture from wildlife: The Panthera onca case to preserve a south American endangered species. Current Protocols in Molecular Biology, 116, 28.7.1-28.7.14. https://doi.org/10.1002/cpmb.25

Mishra, B., Ragini, S. R., Kashiv, I. L., \& Ratho, R. K. (2010). Preservation of continuous cell lines at $-85^{\circ} \mathrm{C}$ : A low-cost alternative for resource limited countries. Indian Journal of Pathology \& Microbiology, 53(4), 742-744. https://doi.org/10.4103/03774929.72068

Moore, J., \& Maitland, D. (2014). Biomedical technology and devices (2nd ed., pp. 295275). Boca Raton: CRC Press.

Neuhuber, B., Swanger, S. A., Howard, L., Mackay, A., \& Fischer, I. (2008). Effects of plating density and culture time on bone marrow stromal cell characteristics.
Experimental Hematology, 36(9), 1176-1185. https://doi.org/10.1016/j. exphem.2008.03.019

Orazizadeh, M., Hashemitabar, M., Bahramzadeh, S., Dehbashi, F. N., \& Saremy, S. (2015). Comparison of the enzymatic and explant methods for the culture of keratinocytes isolated from human foreskin. Biomedical Reports, 3(3), 304-308. https://doi.org/10.3892/ br. 2015.442

Pavel, M., Renna, M., Park, S. J., Menzies, F. M., Ricketts, T., Füllgrabe, J., ... Rubinsztein, D. C. (2018). Contact inhibition controls cell survival and proliferation via YAP/TAZautophagy axis. Nature Communications, 9(2961), 1-18. https://doi.org/10.1038/ s41467-018-05388-X

Phipps, S. M., Berletch, J. B., Andrews, L. G., \& Tollefsbol, T. O. (2007). Aging cell culture: Methods and observations. Methods in Molecular Biology (Clifton, N.J.), 371, 9-19. https://doi.org/10.1007/978-1-59745361-5 2

Rottem, S., Kosower, N., \& Kornspan, J. (2012). Contamination of tissue cultures by Mycoplasmas; in biomedical tissue culture (pp. 35-58). United Kingdom: IntechOpen Limited.

Ryder, O. A., \& Onuma, M. (2018). Viable cell culture banking for biodiversity characterization and conservation. Annual Reviews of Animal Biosciences, 6, 8398. https://doi.org/10.1146/annurevanimal-030117-014556

Schulz, R., Noelker, L. S., Rockwood, K., \& Sprott, R. L. (2006). The encyclopedia of aging (pp. 191-195). New York: Springer.

Seluanov, A., Vaidya, A., \& Gorbunova, V. (2010). Establishing primary adult fibroblast cultures from rodents. Journal of Visualized Experiments: JoVE, (44), 2033. https://doi.org/10.3791/2033

Siengdee, P., Klinhom, S., Thitaram, C., \& Nganvongpanit, K. (2018). Isolation and 
culture of primary adult skin fibroblasts from the Asian elephant (Elephas maximus). PeerJ, 6, e4302. https://doi.org/10.7717/ peerj.4302

Uphoff, C. C., \& Drexler, H. G. (2004). Detecting Mycoplasma contamination in cell cultures by polymerase chain reaction. Methods in Molecular Medicine, 88, 319-326. https:// doi.org/10.1385/1-59259-406-9:319

Wagner, J., Damaschke, N., Yang, B., Truong, M., Guenther, C., McCormick, J., Huang, W., \& Jarrard, D. (2015). Overexpression of the novel senescence marker $\beta$-galactosidase (GLB1) in prostate cancer predicts reduced PSA recurrence. PloS One,
10(4), e0124366. https://doi.org/10.1371/ journal.pone. 0124366

Walcott, B., \& Singh, M. (2017). Recovery of proliferative cells up to 15- and 49-day post-mortem from bovine skin stored at $25^{\circ} \mathrm{C}$ and $4^{\circ} \mathrm{C}$, respectively. Cogent Biology, 3(1), 1333760. https://doi.org/10.1080/233 12025.2017.1333760

Yang, H., Wang, H., Ren, J., Chen, Q., \& Chen, Z. J. (2017). cGAS is essential for cellular senescence. Proceedings of the National Academy of Sciences of the United States of America, 114(23), E4612-E4620. https:// doi.org/10.1073/pnas.1705499114 